Revista de

Contabilidade e

Organizações

www.rco.usp.br
DOI: http://dx.doi.org/10.11606/rco.v7i18.55427
Journal of

Accounting and

Organizations

\title{
Corporate social reporting practices of French and Brazilian Companies: a comparison based on institutional theory
}

\author{
Marcelle C. Oliveira $^{\mathrm{a}}$; João E. Ponte Junior ${ }^{\mathrm{b}}$; Oderlene V. Oliveira ${ }^{\mathrm{c}}$ \\ ${ }^{a}$ Faculdade de Economia Administração, Atuária, Contabilidade e Secretariado Executivo - Universidade Federal do Ceará \\ ${ }^{b}$ Faculdade Metropolitana da Grande Fortaleza \\ c Programa de pós-graduação em Administração de Empresas - Universidade de Fortaleza
}

\section{Article Info}

\section{Article history}

Received: 8 May 2012

Accepted: 10 March 2013

Key words

Corporate Social Reporting Practices

Institutional Theory

Disclosure

\begin{abstract}
The objective of this study is to determine whether or not social information disclosure practices of the top 15 Brazilian and top 15 French companies listed in the Forbes global ranking differ due to company size, country of origin, using the 16 indicators of the United Nations publication 'Guidance on Corporate Responsibility Indicators in Annual Reports' as benchmark. The empirical evidence is further analyzed using Institutional Theory as support. The study is based on a literature review and documents issued by the companies in the selected sample. The methodology is exploratory, quantitative and qualitative. The results revealed that disclosure practices by companies in both countries are similar, with no statistical significance connected to company size or country of origin. This result can further be explained by institutionalism in each country, a key featured that made it possible to use Institutional Theory as an important support to the main empirical results of the study
\end{abstract}

Copyright $($ C 2013 FEA-RP/USP. All rights reserved.

\section{INTRODUCTION}

Recent studies have made company managers aware of the advantage of adopting good corporate social reporting practices even before they become required by law. Branco and Rodrigues (2008) analyzed the factors influencing social information disclosure by companies traded on the Portuguese stock exchange in 2004 and concluded that companies should see in the level of disclosure an expression of their social and environmental conduct and appreciate the power of disclosure to improve the company image, legitimize company activities and reduce risks to investors.

Parsa and Kouhy (2007) analyzed the social information disclosure practices of small and mediumsized companies listed on the Alternative Investment Market (AIM) in the United Kingdom (UK). Since companies on the AIM were left out of the sample their results cannot not be generalized, not even to the

Corresponding author: $\mathrm{Tel}+5585$ 3366-7802

E-mail: marcellecolares@uol.com.br (M. C. Oliveira); joaoesio@hotmail. com (J. E. Ponte Junior); oderlene@hotmail.com (O. V. Oliveira).

Universidade Federal do Ceará - Departamento de Contabilidade. Avenida da Universidade, 2431, Benfica 60020-180 - Fortaleza, CE - Brasil
UK. In contrast with mainstream recommendations on social information disclosure, the authors concluded that stability acquired throughout a company's existence is not necessarily related to its level of social information disclosure. In addition, they observed a direct correlation between company size and level of disclosure and found that the managers of large and medium-sized companies were aware of the positive effects of social information disclosure on corporate reputation.

In an empirical study based on a sample of 284 companies registered with the Financial, Accounting and Actuarial Research Institute Foundation (FIPECAFI), Cunha and Ribeiro (2007) compared corporate social reporting structures in Brazil and several other countries and concluded that social information disclosure practices vary according to the country of origin. However, most social reports collected for analysis were limited to information on human resources, with the exception of the Portuguese model which included the item 'value added', although no information was provided on composition and calculation.

Considering the efforts of Brazilian and international agencies of corporate social responsibility (CSR) to encourage good quality social reporting and the plethora of available studies indicating divergences in disclosure according to company size, sector, country and type of 
information, the main objectives of this investigation were to determine whether the social information disclosure practices of the top 15 Brazilian and 15 French companies listed in the 2008 Forbes global ranking (top 2,000 companies in the world based on sales, profits, assets and market value) vary according to company size and country of origin, using the UN publication 'Guidance on Corporate Responsibility Indicators in Annual Reports' as benchmark; and to identify the elements in Institutional Theory supporting the respective reporting practices.

To approach the main objectives, four specific objectives were established:

Present the relationship among the Stakeholder Theory, Voluntary Disclosure Theory and Legitimacy Theory and the corporate social disclosure;

Discuss the theoretical framework of corporate social responsibility and disclosure in light of Institutional Theory;

Investigate the relation between the level of social information disclosure and the variables 'company size' and 'country of origin';

Compare Brazilian and French companies with regard to social information disclosure practices and identify the elements in Institutional Theory supporting our findings.

Based on the research proposal, the following a general hypothesis is formulated:

When observed in light of the UN publication 'Guidance on Corporate Responsibility Indicators in Annual Reports', the social information disclosure practices of the French and Brazilian companies in the sample vary according to company size and country of origin.

To meet the specific objectives of the study, the following two secondary hypotheses are formulated:

- The level of social information disclosure is higher in French companies than in Brazilian companies.

- The level of social information disclosure is positively correlated with company size.

The study makes an important contribution to the status quaestionis of social information disclosure by large companies in relation to UN recommendations an area which has received little attention so far. It does so by making a pertinent comparison between the disclosure practices of Brazilian and French companies (France was the first country to regulate corporate social reporting) and by interpreting disclosure patterns according to the Institutional Theory.

\section{LITERATURE REVIEW}

\subsection{Stakeholder theory, voluntary disclosure theory, legitimacy theory and corporate social disclosure}

Gray (2000) highlights the importance of research on social and environmental disclosure with the purpose of presenting how the companies systematically identify, register, measure and publish information on their corporate socioenvironmental management.

Many theories such as Stakeholders Theory, Legitamacy Theory and Voluntary Disclosure Theory have been used to explain the corporate social disclosure. Social information may be included in standard accounting reports or disclosed through separate publications (Alam, 2006), such as special reports for specific groups of stakeholders containing multidimensional socioenvironmental information and descriptions of initiatives of commitment to sustainable development.

Some consider that the interaction between the organization and stakeholders influences the level of social information disclosure of the organization (Deegan; Blomquist, 2006; Elijido-Tem, 2004; Ruf et al., 2001; Walden; Schwartz, 1997; Patten, 1992). Others consider that the search for legitimacy influences the level of social information disclosure of the organization and they use the Legitimacy Theory approach to explain the firms behaviour about this (Brown; Deegan, 1998; Deegan; Rankin; Tobin, 2002).

Voluntary Disclosure Theory has been expanded to include environmental and social information disclosure (Verrecchia, 1983; Rover et al, 2009). According to Dye (apud Salotti \& Yamamoto, 2005), Voluntary Disclosure Theory may be regarded as a special instance of Game Theory, based on the assumption that an organization contemplating disclosure will only disclose information favorable to itself. In addition to this approach, Hendriksen and Van Breda (1999) see disclosure not as a theory, but as a practice with a number of implications.

According to Faria and Pereira (2009, p. 3), without proper information disclosure, stakeholders are unable to analyze and follow the activities of the organization, let alone determine whether it is socioenvironmentally responsible. According to Bushman and Smith (2003 apud Cunha; Ribeiro, 2006), information plays a central role in the management of conflicts of interests and in the reduction of information asymmetry between managers and investors.

As described by Deegan (2006), Legitimacy Theory has been used to explain the voluntary disclosure of socioenvironmental information by large corporations through reports (such as sustainability reports) published as supplements to mandatory financial statements, using specifically designed disclosure models. According to Dias Filho (2007), in the context of Legitimacy Theory, social information disclosure is a means to acquire, 
sustain and recover legitimacy within the social system. However, the approach may be complemented by Stakeholder Theory which identifies specific groups of stakeholders, their expectations and their relative power over the organization.

\subsection{The evolution of institutional theory}

Institutional Theory has been used as an approach to interpret phenomena related to isomorphism, legitimacy and influence in the corporate environment. In general, the theory supports the central process of creation and perpetuation of lasting social structures. Independent initiatives from within the corporation influence the environment and, once institutionalized, are adopted or copied by other organizations.

In spite of its current relevance, Institutional Theory dates from the nineteenth century. The theory rejects rationalistic logic, especially in the form of economic rationalism, according to which all economic behavior may be explained by a continuous and directed effort to maximize individual gain. In contrast, Institutional Theory posits that individuals make decisions based not only on rational analysis but also, and perhaps even more often, on preexisting institutionalized options.

The history of Institutional Theory is not linear. After a long period of popularity, academic interest ebbed between the late 1940s and the early 1970s, followed by a revival in the late 1970s. As a result of this waning and waxing, there are now two dominant trends in Institutional Theory: old (or historic) institutionalism and new institutionalism.

Presently, Institutional Theory covers three important aspects: institutions, institutionalized structures and institutionalization processes, each of which has been accentuated by different scholars throughout the history of the theory. For example, early academic exploits centered on the nature and implications of institutions in recognition of the then growing importance of organizations to society and the institutional nature acquired by some of these organizations.

Other sciences, especially economics, sociology and political science, have also invested much effort in the study of the nature of institutions. The studies produced in these three areas of science are reflected in the three dimensions - political, economic and sociological — of both old and new Institutionalism (SCOTT, 2008).

Thus, despite its overall consistency, Institutional Theory has over time incorporated contributions from a number of scholars favoring different approaches and emphasizing different conceptual aspects. Nevertheless, the most significant contributions to the concepts of institution and the institutionalization process have come from the field of sociology.

\subsubsection{New institutionalism}

Institutional Theory offers an alternative to the utilitarianism and functionalism of the concept of costbenefit and the unrelenting pursuit of efficiency by affirming that the process of choice is not necessarily moved by rationality. In addition, in view of the complexity of reality, Institutional Theory assumes humans are ontologically limited in their ability to predict with precision the results of the decisions they make.

As an important contribution to the understanding of the decision-making process, Institutional Theory asserts that individuals do not always rationalize decisions, but often choose from a set of preexisting institutionalized options. In other words, institutionalization simplifies reality by limiting the set of possible decisions provided by organizing rationality, such as options already tested and approved by other organizations under similar circumstances.

According to new Institutional Theory, because formal structures have both symbolic properties and the ability to generate action, they are rife with socially shared meanings. Thus, in addition to action-related objective functions, formal structures help keep the organization's internal and external public informed of its socioeconomic status (DIMAGGIO; POWELL, 1991).

New Institutionalism rejects the central functionalistic claim that structural arrangements are defined solely by the internal characteristics of the organization, such as company size and technology (DONALDSON, 1999), and claims that structures are a priori determined by both internal and external factors (eg, changes in legislation) or even by the development of social norms within the organizational network.

This links new Institutionalism to CSR, which is perceived as a social norm. The organizational network may be a specific sector in which certain social norms are prevalent. For example, social information disclosure may be stronger in certain sectors. This may of course be due to stricter norms, but in some cases companies will adhere to a set of socially correct attitudes even in the absence of specific regulations.

Old and new institutionalism also differs with regard to the aspect of autonomy. In the former, organizations are relatively autonomous in relation to the environment; in the latter, organizations as susceptible to pressure from the environment in an almost deterministic fashion.

Following the same line of reasoning, Scott (2008) points out that there are two levels of institutional environment: a general level and an immediate level. In the former, organizations are affected in a general way by globally accepted rules and norms. In the latter, the aspects of dependence and power are prevalent as companies are influenced by geographical proximity to larger and more successful organizations.

The notion of different levels of institutional environment may be illustrated by two scenarios: similar 
companies in geographical proximity often have certain locally institutionalized structures in common (immediate level), whereas other, globally accepted practices and structures may be adopted by geographically unrelated companies (general level). Both are the result of the convergence of a number of factors related to efficiency, beliefs and moral values. Practices at the general level tend to display greater maturity than practices at the local or immediate level.

Formal structures, as we have said, have both symbolic properties and the ability to generate efficacious action. Consequently, such structures have objective and concrete functions while communicating the identity of the organization to the external and internal public. According to Scott (2008), organizations do not adopt structures solely for the sake of efficiency, but also in order to acquire legitimacy and social acceptance. In this context, it should be pointed out that when an action is disseminated, it not only lead to increased practical efficiency, but it creates symbols (or "myths") which become acknowledged by environmental actors over time. The degree of institutionalization of a practice is inversely proportional to the degree of circumspection with which it is received: the more strongly institutionalized it is, the less it is questioned by new adepts.

This allows us to draw some inferences. First, similarities between organizations may be explained by either immediate or general institutional arrangements. If, however, such similitude occurs in geographically distant organizations, it is likely the result of general institutionalism. On the other hand, if similitude is observed in organizations in close geographical proximity, and nowhere else, it is most likely due to isomorphism at the immediate level. In addition, institutionalized structural arrangements tend to be less stable at the local level than at the general level, probably because they are less mature.

Homogeneity in company structures and actions may be explained by the notion that organizations make decisions by choosing from a set of environmentally institutionalized options in order to acquire social acceptance. Thus, homogeneity may be interpreted in light of 'similitude' and 'isomorphism' - principles of Institutional Theory (DIMAGGIO; POWELL, 1991).

\subsubsection{Mechanisms of isomorphism}

According to Carvalho, Vieira and Lopes (1999), the institutional approach assumes organizations are influenced by regulations issued by the government and other regulatory bodies. Organizations therefore seek to adjust their structures and procedures to the cultural expectations of the societal context in which they are inserted.

Through mechanisms of isomorphism, large organizations exert formal and informal pressures on smaller organizations which may be dependent on them, as illustrated by the relationship between parent companies and their subsidiaries (DIMAGGIO; POWELL, 1991).

The authors classified the mechanisms of isomorphism into 'coercive', 'normative' and 'mimetic'. The contribution of each mechanism depends on local context and type of society. For example, normative isomorphism is often observed in contexts with a strong democratic tradition and a high level of competition. Coercive isomorphism is more characteristic of patrimonialistic, authoritarian and government-controlled regimes. Mimetic isomorphism occurs when organizations adopt practices and processes from successful organizations belonging to the same environment.

The process of mimetic isomorphism was illustrated in a study by Moura and Dias Filho (2009) who demonstrated that smaller banks tend to emulate the disclosure models and practices adopted by larger banks. The study confirmed the hypothesis that when organizations are faced with uncertainties and threats to their survival, they model themselves on organizations which they perceive as efficient. This behavior is in perfect agreement with the tenets of Institutional Theory.

Consultancy is another example of mimetic isomorphism. When consultants are hired by companies to troubleshoot, they employ the know-how they have accumulated over time and, by way of mimetic isomorphism, eventually contribute to institutionalize procedures adopted by other organizations.

Similitude is promoted in the organizational environment by the adoption of common market practices facilitating transactions between organizations that acknowledge the importance of socially acceptable rules. In addition, organizational similitude plays an important role in the establishment of partnerships between companies looking to complement their competences.

It is clear, therefore, that the environment gives rise to new elements which eventually become necessary structures, adopted by other organizations in need of social acceptance. In fact, the incorporation of institutionalized practices and processes is viewed by scholars as an indicator of efficiency and modernity. By adopting such standards, organizations safeguard their societal legitimacy and reinforce expectations of continuity, regardless of the immediate efficacy of the adopted practices (TOLBERT; ZUCKER, 1999).

Institutional Theory can explain structures such as formal hiring policies, accounting and budgetary practices, positions or associated functions and occupational equity. In the perspective of Institutional Theory, the adoption of these structures does not necessarily entail increased efficiency and operationality - in fact, it is an expression of acceptance of the formal structures per se rather than a precise assessment of potential results.

An interesting case discussed by Moll, Burns and Major (2006) provides an example of practices adopted not primarily because of the prospect of improved 
performance. The case - originally described in a study by Ansari and Euske (1987 apud MOLL; BURNS; MAJOR, 2006) - involved the adoption of a cost accounting system by the United States Department of Defense (DoD). The old system, considered to be outdated, was replaced to persuade Congress of the efficiency of the Department's cost accounting services. However, as shown by the authors, the new system was neither entirely appropriate for the purpose, nor did it improve efficiency. The DoD was merely conforming to pressures from the environment.

The same authors discussed a study published in 1994 by Hoque and Hopper, who investigated the external factors determining the choice of a management control system for a jute mill in Bangladesh. The study revealed that the new system, which did little to control activities at the mill, had not been adopted to improve management but primarily to meet the demand for external legitimacy.

It is only natural that organizations should permanently wish to improve their efficiency, but organizational efficiency clearly involves not only the rationalization of productive processes, but also cultural elements which depend on subjective variables, such as external legitimacy, to obtain a running supply of inputs and resources and safeguard the survival of the organization.

According to Tolbert and Zucker (1999), to be institutionalized, a structure must be deemed efficacious and necessary by the members of a given social group. The importance of institutionalized structures lies in their power to generate stable behavior patterns. However, this will only happen if they are perceived as legitimate by the target public.

Institutionalized structures which do not safeguard social legitimacy by increasing the visibility of the organization or the respective industry are probably related to factors not covered by Institutional Theory. A classic example of an institutionalized structure justified by the institutional approach is social information disclosure: targeted at a specific public, it increases visibility and creates expectation of social legitimacy and approval. In their discussion of structural arrangements, Tolbert and Zucker (1999, p. 208) stated that even when such arrangements are not entirely efficient, they may still serve to promote the company's image.

Moura and Dias Filho (2009) found that uncertainties inherent in the decision-making process can contribute to the practice of mimetic isomorphism. Uncertainty may be related to the choice of a given structure or to the macroeconomic situation of a moment of crisis. In response, companies try to protect their formal structures by incorporating institutionalized myths which they expect will bring them legitimacy and, consequently, increase chances of survival.

As we have seen, the adoption of organizational structures may be influenced by a number of different circumstances. Contrary to some organizational theories, the quest for operational and managerial efficiency is only one of many aspects to consider.
2.3 Institutional
and
Corporate
Social
Responsibility (CSR)

Organizations adopting CSR concepts and practices, and the impact thereof, have been shown to be determining factors in the institutionalization process. It is therefore pertinent to investigate the relationship between CSR and institutionalism. In this respect, social/sustainability reports and CSR indicators constitute an important tool in the evaluation of the impacts produced by the adoption and dissemination of socially responsible practices.

Although some have questioned the validity of CSR indicators, the contribution of new Institutional Theory to the establishment of CSR is undisputable. When discussing the importance of results analysis for the institutionalization process, Tolbert and Zucker (1999, p.206) argued that the spreading of a process is structure-dependent and may be truncated due to lack of demonstrable results associated with it. Thus, analysis and evaluation are highly relevant conditioning factors.

Considering the impact of the adoption of CSR, as shown by the analysis of indicators, and the profound change in the organizational environment wrought by the dissemination of these practices, the structure 'corporate social responsibility' is likely to become strongly institutionalized, suggesting an urgent need for improved understanding, for the establishment of a concentric knowledge base including the many aspects of CSR, and for the development of a new and unique body of theory.

According to Institutional Theory, institutionalizing a given structure requires a running analysis, evaluation and dissemination of the early impacts of that structure. This is precisely what is now occurring with CSR. Researchers and international agencies investigating how organizations are evaluating and spreading their social actions have among other things found that the replication of academic studies based on CSR indicators is consistent with the theoretical framework of the institutionalization process of corporate social responsibility. The bottom line is: the sedimentation of a structure is necessarily preceded by a period of evaluation and dissemination.

\subsection{Institutional theory applied to accounting science}

As a social science, accounting is by definition dynamic and evolves along with the societal context in which it is inserted. Moura and Dias Filho (2009, p.5) believe that, rather than being a static and purely technical subject, accounting requires continuous adjustment to the changing needs of organizations and their respective social environments. Institutional Theory-an eminently social theory - can therefore help explain the response of accounting science to environmental change.

According to Dias Filho and Machado (2004, p.32), Institutional Theory has been much advocated by 
researchers looking to explain accounting practices by reference to context. However, despite the classification of Institutional Theory into three dimensions (political, sociological and economic), no accounting dimension has as yet been defined.

The intersection between Institutional Theory and accounting lies in the assumption that intraorganizational structures and processes, including accounting, are adopted for reasons of environmental pressure rather than as a means of cost reduction (MOLL; BURNS; MAJOR, 2006). In other words, if an accounting structure is appropriate for the organizational environment, it will be adopted regardless of functional efficiency. The reason for adopting the structure is the need for legitimacy through adjustment to external pressures, even if it goes against the quest for internal efficiency.

Scholars have used Institutional Theory to explain how the adoption of a given accounting system may be understood in terms of adjustment to external pressures (MOLL; BURNS; MAJOR, 2006, p.187). Undeniably, Institutional Theory sheds light on many of the functions of accounting in society.

As explained by Scott (2008), institutions may be transported by different means, cultures, structures and routines. The approach helps explain an array of empirical findings related to the adoption of accounting structures. These means of transportation or vectors may, according to the author, operate at different environmental levels, in a clear reference to the two levels, immediate and general, of Institutionalism.

Likewise, Moll, Burns and Major (2006) point out that although institutions are the result of human activity, the adoption of institutionalized practices under the influence of external pressures is not always a conscious process. In real life, organizational structures and processes do not necessarily correspond to their external appearances and expectations, but may be maintained by mechanisms of isomorphism (mainly of the coercive kind) resulting from laws and regulations.

In accounting, coercive isomorphism may be the result of government policies, regulations or relationships with suppliers. These factors exert pressure on organizations to adopt specific internal structures and procedures. On the other hand, sometimes similitude in accounting practices is simply the result of mimetic isomorphism, as when organizations imitate the successful practices of their competitors.

Finally, studies on normative isomorphism have illustrated how organizations adopt procedures and structures advocated by dominant professions, such as respected professionals or consulting bodies. In the perception of Moll, Burns and Major (2006), the notion of different types of isomorphism may be used to support the results of studies in accounting science.

Carpenter and Feroz (2001) investigated the adoption of accounting principles generally accepted in New York accounting reports and found that adoption was driven by the need for legitimacy and influenced by power plays involving intraorganizational policies.

\section{METHODOLOGICAL PROCEEDINGS}

Proceeding deductively, from theory to the empirical field, this exploratory, quantitative and qualitative study was based on a review of the literature and documents issued by the companies in the sample, with the purpose of comparing Brazilian and French practices of social information disclosure. The observed practices were analyzed and compared against the benchmark "Guidance on Corporate Responsibility Indicators in Annual Reports", published by the UN in 2008 .

The study was exploratory in view of the scarcity of studies in the field of social information disclosure by companiescomparedagainsthelatestUNrecommendations of corporate responsibility and interpreted in light of Institutional Theory. It was qualitative because data were collected from a non-probabilistic sample and submitted to content analysis, and it was quantitative due to the use of statistics to investigate the correlation between variables (company size, country of origin and level of disclosure).

The documents reviewed for the study included annual financial and socioenvironmental reports issued by the companies in the sample. The financial documents consisted of management reports, balance sheets, annual results reports, explanatory notes in standard financial reports and statements issued by independent auditors. The socioenvironmental documents (usually published in separate) included sustainability reports in the GRI-G3 format (Global Reporting Initiative) and social balance in the IBASE format (Brazilian companies) or rapport développement durable, bilan social and GRI (French companies). The two types of report were accessed directly on the respective company websites.

If the companies of the two countries published Value Added Statement (VAS) it could be useful to investigate the indicators of the group "Trade, investment and others", such as "Total Revenues" and "Local Purchasing", but the VAS is mandatory only for some Brazilian companies, not to all of them, nor to French companies, so we didn't consulted this document (when it was published by Brazilian companies in the sample).

The review of the literature focused on sources relevant to the establishment of a dialogue between the different approaches and elements of Institutional Theory which support the concept of corporate social responsibility.

As in previous comparative studies, our study sample consisted exclusively of large corporations. For reasons of equity, all companies were chosen from the list of the 2,000 largest corporations in the world published by Forbes in 2008. The methodology used to compile the Forbes global ranking is not based on sales figures alone (which would give a false impression of company size), but uses a composite score based on sales, profits, assets 
and market value.

So, we consider its methodology an advantage if compared to that used by other rankings, and the fact that the Forbes ranking to list 2000 companies become possible to choose 15 Brazilian and 15 French companies, because important rankings that lists only the 500 major companies around the world didn't have in this amount even 15 companies from each of these countries we selected to study CSR.

Neither all companies in the ranking of Forbes are listed in the stock market. We choose only listed companies to the sample, that consisted of the top 15 French companies on the Forbes global ranking traded on the stock market of Paris and the top 15 Brazilian companies on the Forbes global ranking traded on the stock market of São Paulo. We consider it is a reasonable amount of companies from each country and we chose to work with publicly traded companies to ensure greater comparability between companies from different countries and because companies tend to have greater visibility and, consequently, offer easier access to social information, thereby increasing the feasibility of our study.

To better visualize the data and understand the analysis, Table 1 shows 6 groups (categories of analysis) with a total of 16 indicators of corporate social responsibility (subcategories of analysis), the disclosure of which is recommended by the UN.

Table 1. Categories and subcategories of analysis

\begin{tabular}{|c|c|}
\hline Categories & Subcategories \\
\hline \multirow{4}{*}{$\begin{array}{l}\text { Trade, investment and } \\
\text { others }\end{array}$} & 1. Total revenues \\
\hline & 2. Value of imports vs. exports \\
\hline & 3. Total new investments \\
\hline & 4. Local purchasing \\
\hline \multirow{4}{*}{$\begin{array}{l}\text { Employment creation and } \\
\text { labor practices }\end{array}$} & 5. Total workforce with breakdown by employment type, employment contract and gender \\
\hline & 6. Employee wages and benefits with breakdown by employment type and gender \\
\hline & 7. Total number and rate of employee turnover broken down by gender \\
\hline & 8. Percentage of employees covered by collective agreements \\
\hline \multirow{3}{*}{$\begin{array}{l}\text { Technology and human } \\
\text { resource development }\end{array}$} & 9. Expenditure on research and development \\
\hline & 10. Average hours of training per year per employee broken down by employee category \\
\hline & 11. Expenditure on employee training per year per employee broken down by employee category \\
\hline \multirow{2}{*}{ Health and safety } & 12. Cost of employee health and safety \\
\hline & 13. Work days lost due to occupational accidents, injuries and occupational illness \\
\hline \multirow{2}{*}{$\begin{array}{l}\text { Government and } \\
\text { community Contributions }\end{array}$} & 14. Payments to government \\
\hline & 15. Voluntary contributions to civil society \\
\hline Corruption & $\begin{array}{l}\text { 16. Number of convictions for violations of corruption-related laws or regulations and amount of } \\
\text { fines paid/payable. }\end{array}$ \\
\hline
\end{tabular}

Source: Translated and adapted from United Nations (2008).

Data were collected with the use of an instrument translated and adapted from "Guidance on Corporate Responsibility Indicators in Annual Reports" (UN, 2008) (Annex A) and interpreted with the aid of content analysis. The data collected from each firm were analyzed with regard to adherence to UN recommendations in each subcategory.

To quantify the level of disclosure of each CSR indicator in relation to $\mathrm{UN}$ recommendations, the information collected from company reports was scored as follows:

0 - none: no disclosure of any aspect of the indicator.

1 - partial: disclosure of some, but not all aspects of the indicator.

2 - full: disclosure of all aspects of the indicator, as recommended by the UN.

The classification reflects the different ways in which companies disclosed the content of each indicator: some indicators were absent from company reports, some were disclosed in full, as recommended by the UN, and some were only partly disclosed.
Each firm in the sample could score a minimum of zero points (in case of null disclosure of all 15 indicators) and a maximum of 30 points (in case of full disclosure of all 15 indicators). After the data of each firm were collected, they were organized in tables and consolidated. The statistical analysis was performed with the software SPSS (v. 16.0) and Microsoft Excel 2007. The procedure made it possible to compare French firms to Brazilian firms with regard to the level of social information disclosure.

The qualitative variable 'level of social information disclosure' was quantified for each company (scoring range: $0-30$ ). It should be noted that the subcategory "value of imports vs. exports" was excluded from the analysis because it was not applicable to financial institutions, represented in our sample by 7 banks (BNP Paribas, Societé Générale, Crédit Agricole, Itaú S.A, Banco do Brasil S.A, Unibanco and Banco Bradesco) and 1 insurance company (AXA group). The final analysis therefore included only 15 subcategories.

Figure 1 presents an overview of the findings of social information disclosure by the top 15 Brazilian and top 15 French companies on the 2008 Forbes ranking in relation to the CSR indicators recommended in the UN guide. 
Figure 1. Disclosure of UN-recommended CSR indicators by the companies in the sample

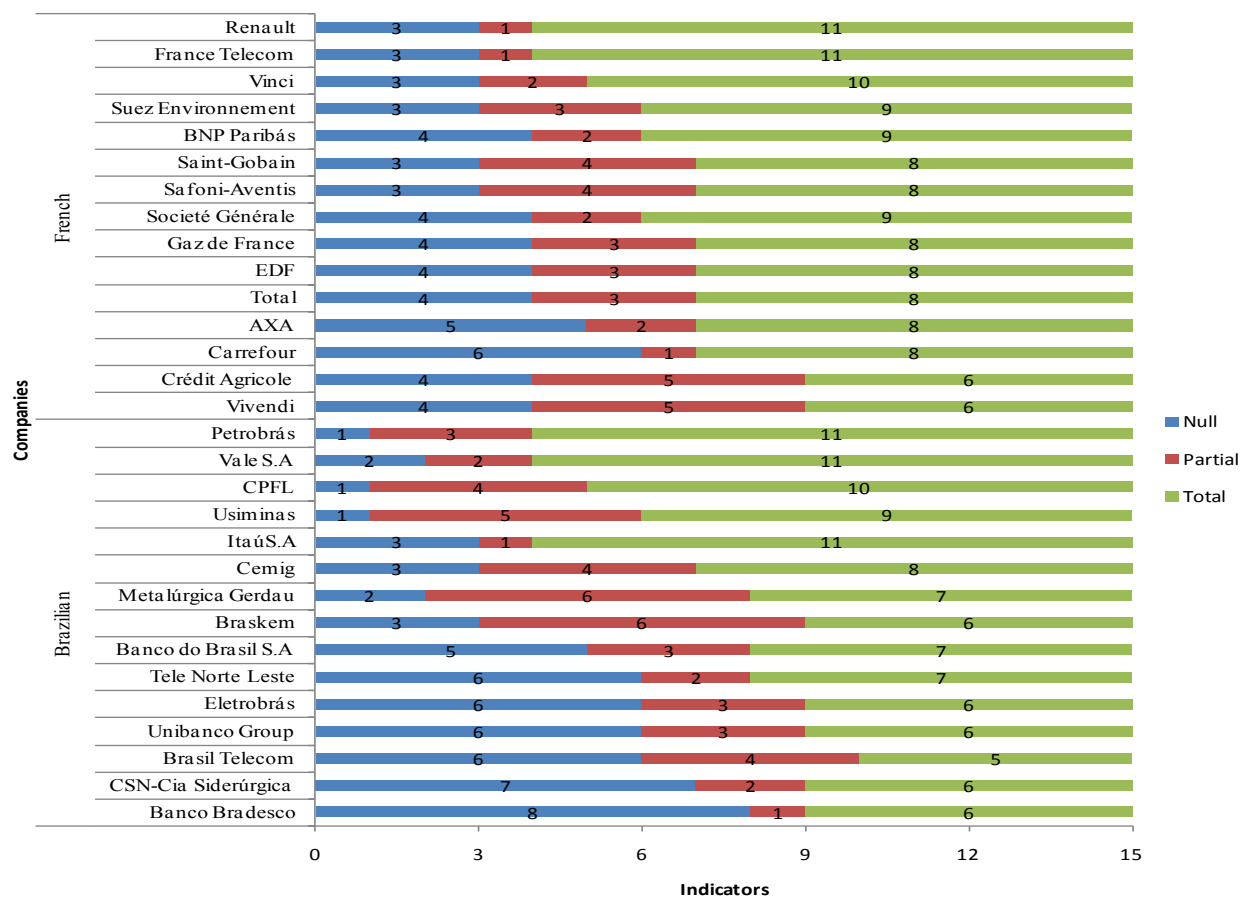

Source: Elaborated by the authors.

Figure 2 presents an overview of absolute scores of social information disclosure of UN-recommended CSR indicators by the top 15 Brazilian and top 15 French companies on the 2008 Forbes ranking.

Figure 2. Scores of social information disclosure of UN-recommended CSR indicators by the top 15 Brazilian and

French companies on the 2008 Forbes ranking.

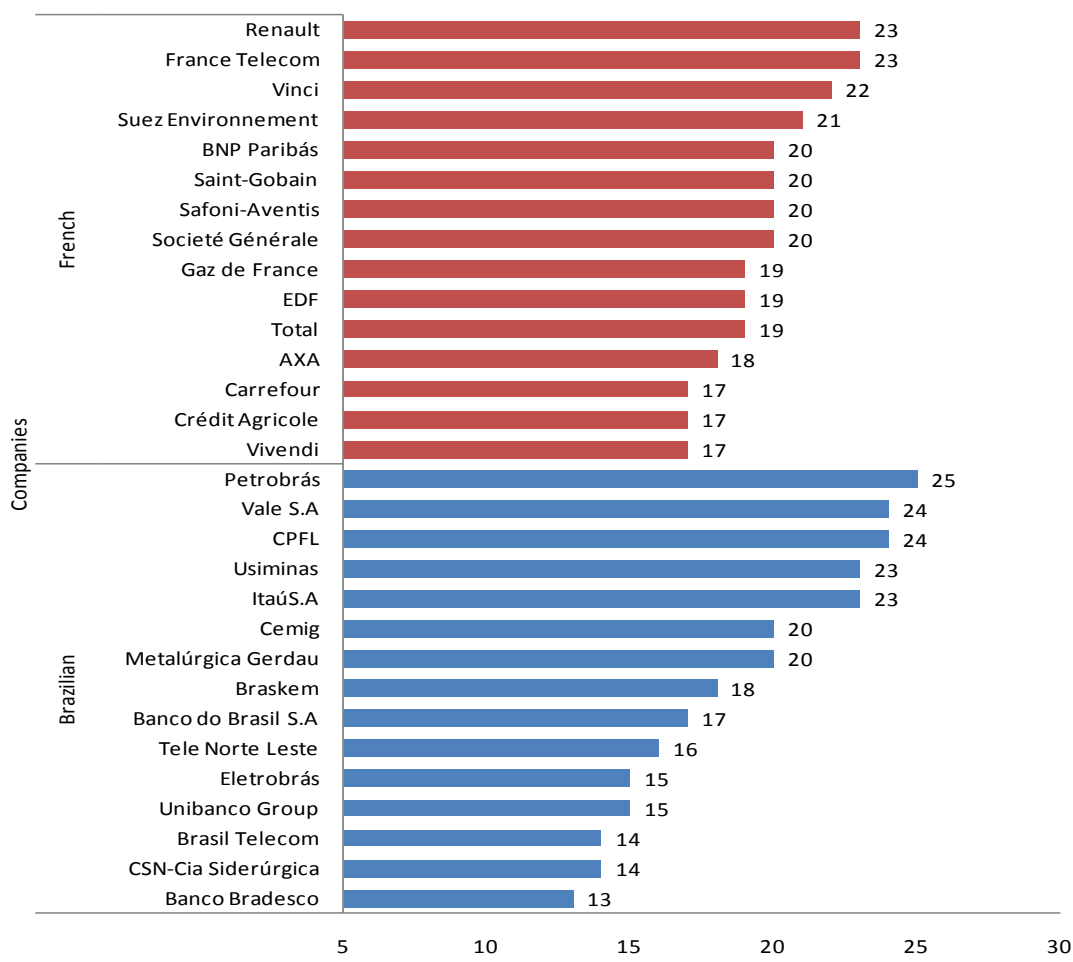

Source: Elaborated by the authors. 
As described above, in the present study the qualitative variable ('level of social information disclosure') was quantified with a 3-point scoring system. The standard deviation was unknown for the population. Two independent samples were used (Brazilian companies and French companies), consisting of 15 elements of each. Comparisons of average values were made between samples and between elements: for example, the level of social information disclosure was compared for Brazilian and French companies (comparison of samples) and for the largest and smallest companies in the sample (comparison of elements).

Based on the criteria published by Stevenson (1981) and Bruni (2007), Student's $t$ test was considered the most appropriate test for the analysis of our findings.

\section{EMPIRICAL EVIDENCE: RESULTS AND ANALYSIS}

To determine whether the level of social information disclosure is correlated with country of origin, the following two hypotheses were formulated:
Null hypothesis $1\left(\mathbf{H}_{0}\right)$ : the average level of social information disclosure is the same in French and Brazilian companies.

Alternative Hypothesis $1\left(\mathbf{H}_{\mathbf{1 a}}\right)$ : the average level of social information disclosure is not the same in French and Brazilian companies.

To determine whether the level of social information disclosure is correlated with company size, as indicated by the Forbes ranking, the following two hypotheses were formulated:

Null hypothesis $2\left(\mathbf{H}_{\mathbf{0 b}}\right)$ : the average level of social information disclosure is the same in both large and small companies of the sample.

Alternative Hypothesis $2\left(\mathbf{H}_{\mathbf{1 b}}\right)$ : the average level of social information disclosure is not the same in large and small companies of the sample.

In all tests, the level of statistical significance was set at $5 \%$. Before analysis with Student's $t$ test, the quantitative variables were tested for normal distribution with the Kolmogorov-Smirnov test (SIEGEL; CASTELLAN JUNIOR, 2006) (see Table 2).

Table 2. Result of one-sample Kolmogorov-Smirnov test for Brazilian and French companies.

\begin{tabular}{|c|c|c|c|}
\hline & & Brazilian Companies & French Companies \\
\hline \multicolumn{2}{|c|}{$\mathrm{N}$} & 15 & 15 \\
\hline \multirow[t]{2}{*}{ Normal parameters $(\mathrm{a}, \mathrm{b})$} & Mean & 1.2400 & 1.3000 \\
\hline & Std. deviation & 0.28234 & 0.13628 \\
\hline \multirow[t]{3}{*}{ Most extreme differences } & Absolute & 0.157 & 0.233 \\
\hline & Positive & 0.157 & 0.233 \\
\hline & Negative & 0.155 & 0.233 \\
\hline \multicolumn{2}{|c|}{ Kolmogorov-Smirnov Z } & 0.607 & 0.904 \\
\hline \multicolumn{2}{|c|}{ Asymp. Sig. (2-tailed) } & 0.855 & 0.388 \\
\hline
\end{tabular}

*a $=$ normal distribution

$* \mathrm{~b}=$ calculated from data

Source: Data collected and elaborated by the authors.

As shown in Table 2, the distribution of the data collected for the variables 'Brazilian companies' and 'French companies' was normal ( $p=0.855$ and 0.388$)$.
The distribution of the data collected for the variables 'largest companies' and 'smallest companies' was normal $(p=0.72$ and 0.89$)$ (see Table 3$)$.

Table 3. Result of one-sample Kolmogorov-Smirnov test for the largest and smallest companies in the sample.

\begin{tabular}{c|c|c|c}
\hline \multicolumn{1}{|c|}{} & Largest companies & Smallest companies \\
\hline $\mathrm{N}$ & & 15 & 15 \\
\hline Normal parameters (a,b) & Mean & 1.3067 & 1.2333 \\
\hline Most extreme differences & Std. deviation & 0.21202 & 0.22887 \\
\hline & Absolute & 0.179 & 0.148 \\
\hline Kolmogorov-Smirnov Z & Positive & 0.179 & 0.120 \\
\hline Asymp. Sig. (2-tailed) & Negative & 0.694 & 0.573 \\
\hline
\end{tabular}

$* \mathrm{a}=$ normal distribution

*b $=$ calculated from data

Source: Data collected and elaborated by the authors.

Using the independent-samples $t$ test option of the Statistical Package for the Social Sciences (SPSS), differences between average values were analyzed (STEVENSON, 1981) (Table 4). 
Table 4. Group Statistics. Result of the $t$ test for independent samples (Brazilian and French companies).

\begin{tabular}{cccccc}
\hline & Country & N & Mean & Std. deviation & Std. error mean \\
\hline Companies & Brazil & 15 & 1.2400 & 0.28234 & 0.07290 \\
\hline & France & 15 & 1.3000 & 0.13628 & 0.03519 \\
\hline
\end{tabular}

Source: Data collected and elaborated by the authors.

Table 5. Independent Samples Test. Result of the $t$ test for independent samples (Brazilian and French companies).

\begin{tabular}{|c|c|c|c|c|c|c|c|c|c|c|}
\hline \multicolumn{4}{|c|}{ Levene's test for equality of variances } & \multicolumn{7}{|c|}{$t$ test for equality of means } \\
\hline & & \multirow[t]{2}{*}{$\mathbf{F}$} & \multirow[t]{2}{*}{ Sig. } & \multirow[t]{2}{*}{$\mathbf{t}$} & \multirow[t]{2}{*}{ df } & \multirow[t]{2}{*}{$\begin{array}{c}\text { Sig. } \\
\text { (2-tailed) }\end{array}$} & \multirow[t]{2}{*}{$\begin{array}{c}\text { Mean } \\
\text { difference }\end{array}$} & \multirow[t]{2}{*}{$\begin{array}{l}\text { Std. error } \\
\text { difference }\end{array}$} & \multicolumn{2}{|c|}{$\begin{array}{l}95 \% \text { confidence } \\
\text { interval of the } \\
\text { difference }\end{array}$} \\
\hline & & & & & & & & & Lower & Upper \\
\hline \multirow{2}{*}{ 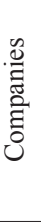 } & $\begin{array}{c}\text { Equal } \\
\text { variances } \\
\text { assumed }\end{array}$ & 12.936 & .001 & -0.741 & 28,00 & 0.465 & -0.06000 & 0.08095 & -0.22581 & .10581 \\
\hline & $\begin{array}{c}\text { Equal } \\
\text { variances not } \\
\text { assumed } \\
\end{array}$ & & & -0.741 & 20.187 & 0.467 & -0.06000 & 0.08095 & -0.22875 & .10875 \\
\hline
\end{tabular}

Source: Data collected and elaborated by the authors.

To test the hypothesis of equality of variances and determine which results to use, Levene's test was applied (SIEGEL; CASTELLAN JÚNIOR, 2006).

If the level of significance is $\leq 0.05$, the hypothesis of equality of variances has to be rejected. Conversely, if the level of significance is $>0.05$, variances may be considered statistically equal (SIEGEL; CASTELLAN JÚNIOR, 2006).
Considering Levene's significance value (0.001), the $t$ test for unequal variances (equal variances not assumed) was chosen. Thus, the test value to be interpreted was $t=-0.741$. Since the significance was $>$ 0.05 , the null hypothesis $\left(\mathrm{H}_{0 \mathrm{a}}\right)$ cannot be rejected; in other words, there was no statistically significant difference between Brazilian and French companies with regard to the level of social information disclosure (see Table 6).

Table 6. Group Statistics. Result of the $t$ test for independent samples (largest and smallest companies).

\begin{tabular}{c|c|c|c|c|c}
\hline & Size & $\mathrm{N}$ & Mean & Std. Deviation & Std. error mean \\
\hline \multirow{2}{*}{ Companies } & Largest & 15 & 1.3067 & 0.21202 & 0.05474 \\
\hline \multirow{2}{*}{} & Smallest & 15 & 1.2333 & 0.22887 & 0.05909 \\
\hline
\end{tabular}

Source: Data collected and elaborated by the authors.

Table 7. Independent Samples Test. Result of the $t$ test for independent samples (largest and smallest companies).

\begin{tabular}{|c|c|c|c|c|c|c|c|c|c|c|}
\hline \multicolumn{4}{|c|}{$\begin{array}{c}\text { Levene's test for equality of } \\
\text { variances }\end{array}$} & \multicolumn{7}{|c|}{$t$ test for equality of means } \\
\hline & & \multirow[t]{2}{*}{$\mathbf{F}$} & \multirow[t]{2}{*}{ Sig. } & \multirow[t]{2}{*}{$\mathbf{t}$} & \multirow[t]{2}{*}{ Df } & \multirow[t]{2}{*}{$\begin{array}{c}\text { Sig. } \\
\text { (2-tailed) }\end{array}$} & \multirow[t]{2}{*}{$\begin{array}{c}\text { Mean } \\
\text { difference }\end{array}$} & \multirow[t]{2}{*}{$\begin{array}{l}\text { Std. error } \\
\text { difference }\end{array}$} & \multicolumn{2}{|c|}{$\begin{array}{l}95 \% \text { confidence } \\
\text { interval of the } \\
\text { difference }\end{array}$} \\
\hline & & & & & & & & & Inferior & Superior \\
\hline \multirow{2}{*}{ 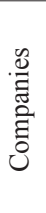 } & $\begin{array}{c}\text { Equal } \\
\text { variances } \\
\text { assumed }\end{array}$ & .588 & .450 & .910 & 28 & 0.370 & 0.07333 & 0.08055 & -0.09167 & .23834 \\
\hline & $\begin{array}{c}\text { Equal } \\
\text { variances not } \\
\text { assumed }\end{array}$ & & & .910 & 27.838 & 0.370 & 0.07333 & 0.08055 & -0.09172 & .23838 \\
\hline
\end{tabular}

Source: Data collected and elaborated by the authors.

As shown in Table 7, with a Levene's significance value of 0.450 , the $t$ test for equal variances was used. The test value to be interpreted was $t=-0.910$. Since the significance was greater than 0.05 , the null hypothesis $\left(\mathrm{H}_{0 \mathrm{~b}}\right)$ cannot be rejected; that is, no statistically significant difference was observed between the largest and the smallest companies with regard to the level of social information disclosure.

\subsection{Interpretation of Results under the Institutional Theory}

The notion of environmental standards related to Institutional Theory can help interpret the empirical findings of hypotheses testing. In a study on the pressures exerted on organizations by different institutional environments, Scott (2008) distinguishes general and 
immediate institutionalism.

In the former, rules and norms affect a set of geographically unrelated organizations in a general manner, favoring the emergence of similitude. In the latter, similitude is observed among geographically related companies due to local factors such as power and dependence. In this case, similitude is the result of the adoption by organizations of certain locally institutionalized practices. Both levels of institutionalism are essentially based on factors related to efficiency, beliefs and moral values, but immediate institutionalism tends to be less stable.

The similitude observed between French and Brazilian companies with regard to social information disclosure may be explained by normative isomorphism and practices institutionalized at the general level. In spite of the geographical distance, the Brazilian and French companies in the sample have homogenous institutional structures and appeared to be influenced by a similar set of social norms typically accepted and disseminated in democratic and competitive environments.

Thus, the perception that CSR is a firmly established social norm, the non-observance of which can compromise the legitimacy and threaten the survival of organizations, may have led the managers of the French and Brazilian companies in our sample to adopt similar institutional arrangements. This interpretation is evidence corroborating our test for the non-rejection of our secondary hypothesis $\left(\mathrm{H}_{0 \mathrm{~b}}\right)$ that the average level of social information disclosure is equal in French than Brazilian companies.

The similitude observed between the largest and smallest companies in the sample with regard to social information disclosure may be explained by immediate institutionalism and mimetic isomorphism. Regardless of country, larger companies exert a local formal and informal pressure on smaller, geographically related companies which depend on them. This dependence can lead to the adoption by smaller companies of locally institutionalized practices.

As we have said, mimetic isomorphism occurs when organizations adopt practices and procedures from successful organizations belonging to the same environment. Thus, it would appear that the smallest companies in the two samples emulated procedures adopted by larger competitors, such as social information disclosure practices, in order to acquire social legitimacy. The observation of social benchmarking is supported by the non-rejection of our secondary hypothesis $\left(\mathrm{H}_{0 \mathrm{~b}}\right)$ that the level of social information disclosure is the same in both large and small companies, as evidenced in our hypothesis testing.

\section{CONCLUSION}

The results of the statistical tests suggest that the hypothesis that social information disclosure practices of French and Brazilian companies are the same no matter the size and country of origin must be rejected.

With regard to country of origin, the level of social information disclosure did not differ significantly between French and Brazilian companies probably due to general institutionalism and normative isomorphism and in spite of the geographical distance and the French pioneering of regulated corporate social reporting in 1977. The perception of CSR as a firmly established social norm, the observance of which can safeguard social legitimacy, is the most likely explanation for the similitude in institutional arrangements observed between the two countries.

With regard to company size, the level of social information disclosure did not differ significantly between the largest and the smallest companies in the sample, probably due to immediate institutionalism and mimetic isomorphism. Regardless of country of origin, larger companies exerted local formal and informal pressure on smaller, geographically related companies. In response, the latter adopted locally instituted practices by way of mimetic isomorphism, such as social information disclosure practices, in order to acquire social legitimacy.

Thus, no significant differences were observed in social information disclosure practices as a result of company size or country of origin. The adoption of social information disclosure practices by the companies in the sample is best understood in light of Institutional Theory.

The study was limited by the small sample size (30 companies) and by the diversity in socioeconomic environment (Brazil and France), even if we consider it is enough to present an overview of the social disclosure by the major companies traded in the stock market of the two countries. It would, however, be interesting to conduct studies based on larger samples of companies from a greater number of countries. Likewise, it would be instructive to investigate the correlation between social information disclosure and variables such as economic sector, time of existence and levels of internationalization, indebtedness, regulation and monopoly.

\section{ACKNOWLEDGMENTS}

The authors would like to thank the National Council of Scientific and Technological Research and Development (CNPq) for financial support.

\section{REFERENCES}

ALAM, Manzurul. Stakeholder theory. In: Z. HOQUE, (Org.) Issues in accounting research: theories and methods. London: Spiramus Press Ltd., 2006.

BRANCO, M. C.; RODRIGUES, L. L. Factors Influencing Social Responsibility Disclosure by Portuguese Companies. Journal of Business 
Ethics, [S.1. : s.n.], 2008.

BROWN, N.; DEEGAN C. The public disclosure of environmental performance information - a dual test of media agenda setting theory and legitimacy theory. Accounting and Business Research, v. 29, n. 1, hiver, 1998.

BRUNI, Adriano L. Estatística Aplicada à Gestão Empresarial. São Paulo: Atlas, 2007.

CARPENTER, V. L.; FEROZ, E. H. Institutional Theory and Accounting Rule Choice: an Analysis of Four US State Governments' Decisions to Adopt Generally Accepted Accounting Principles. Accounting, Organisations and Society, 26, 565596, 2001.

CARVALHO, C. A.; VIEIRA, M. M. F.; LOPES, F. D. Contribuições da Perspectiva Institucional para Análise das Organizações. In: XXIII ENENPAD. Anais... Foz do Iguaçu: ANPAD, 1999.

CUNHA, J. V. Alves; RIBEIRO, M. Souza. Evolução e Estrutura do Balanço Social e Países Selecionados: um Estudo empírico. Revista de Administração Conteporânea-Eletrônica, [S.1. : s.n.], 1 (2), mai/ ago. 2007.

DEEGAN, C. Legitimacy Theory. In Methodological Issues in Accounting Research. Deakin University. London: Spiramus, Jul. 2006.

DEEGAN, C; BLOMQUIST, C. Stakeholder influence on corporate reporting: an exploration of the interaction between WWF-Australia and the Australia Mineral Industry. Accounting, Organizations and Society. v. 31, 2006.

DEEGAN, C; RINKIN, M; TOBIN, J. An examination of the corporate social and environmental disclosures of BHP from 1983-1997: a test of legitimacy theory. Accounting, Auditing and Accountability Journal. v.15, n.3, 2002.

DIAS FILHO, J. M. Políticas de evidenciação contábil: um estudo do poder preditivo e explicativo da teoria da legitimidade. Anais do Enanpad, Rio de Janeiro, RJ, Brasil, 2007, 31.

DIAS FILHO, J. M.; MACHADO, L. H. B. Abordagens da pesquisa em contabilidade. In: IUDÍCIBUS, Sergio de; LOPES, Alexsandro Broedel. Teoria avançada da contabilidade. São Paulo: Atlas, 2004.

DIMAGGIO, P. J.; POWELL, W. W. Introduction. In: DIMAGGiO, P. J.; POWELL, W. W. (Eds.), The new institutionalism in organizational analysis. Chicago: The University of Chicago Press, 1991.
DONALDSON, L. Teoria da Contingência. Estrutural. In: CLEGG, S. R., HARDY, C.; NORD, W. R. (Orgs.) Handbook de Estudos Organizacionais. São Paulo: Atlas, 1999.

ELIJIDO-TEN, E. Determinants of environmental disclosures in a developing country: an application of the stakeholder theory. Singapore: Fourth Asia Pacific Interdisciplinary Research in Accounting Conference, Jul. 2004

FARIA, A. C., PEREIRA, R. S. Disclosure de informações socioambientais pelas maiores empresas do segmento químico e petroquímico no Brasil, a partir da NBC T -15. 33. Anais do Enanpad, 2009, São Paulo, SP, Brasil, 33.

GRAY, R. Current developments and trenes in social and environment auditing, reporting and attestation: a review and comment. International Journal of Auditing. 2000. 4.

HENDRIKSEN, E. S., VAN BREDA, M. F. Teoria da contabilidade. (5th ed.) (A. Z. Sanvicente, Trad.) São Paulo: Atlas, 1999. (Originally published in 1992).

MOLL, Jodie; BURNS, John; MAJOR, Maria. Institutional Theory. In: HOQUE, Zahirul (Org.) Issues in Accounting Research: Theories and Methods. Londres: Spiramus Press Ltda, 2006.

MOURA, F. V.; DIAS FILHO, J. M.. Evidenciação de Cunho Social em Seis Bancos Brasileiros - Uma Análise à Luz da Teoria Institucional. In: XXXIII ENANPAD. Anais... São Paulo: ANPAD, 2009.

PARSA, Sepideh; KOUHY, Reza. Social Reporting by Companies Listed on the Alternative Investment Market. Journal of Business Ethics. [S.l. : s.n.], 2007.

PATTEN, D. M. Intra-industry environmental disclosures in response to the Alaskan oil spill: a note on legitimacy theory. Accounting, Organizations and Society. v. 17, n. 5, 1992.

ROVER, S. et al. Explicações para a divulgação voluntária ambiental no Brasil utilizando análise de regressão em painel. Anais do Congresso Anpcont, São Paulo, SP, Brasil, 3, 2009, junho.

RUF, B. M.; MURALIDHAR, K.; BROWN, R. M.; JANNEY, J. J.; PAUL,K. An Empirical Investigation of the Relationship Between Change in Corporate Social Performance and Financial Performance: A Stakeholder Theory Perspective. Journal of Business Ethic, V. 32, 2001

SALOTTI, B. M., YAMAMOTO, M. M. Ensaio sobre a teoria da divulgação. Brazilian Business Review, 
2005. v. 2, n. 1 .

SCOTT, W. Institutions and Organisations. 3. ed. Sage Publising, London, 2008.

SIEGEL, Sidney; CASTELLAN, N. John Júnior. Estatística não-paramétrica para ciências do comportamento. 2. ed. Porto Alegre: Artmed, 2006.

STEVENSON, William J. Estatística Aplicada à Administração. São Paulo: Harper \& Row do Brasil, 1981.

TOLBERT, Pamela S.; ZUCKER, Lymme G. A instrumentalização da Teoria Institucional. In: CLEGG, S. R., HARDY, C.; NORD, W. R. (Orgs.) Handbook de Estudos Organizacionais. São Paulo: Atlas, 1999.

UNITED NATIONS. Guidance on Corporate Responsibility Indicators in Annual Reports. New York, 2008.

VERRECCHIA, R. E. Discretionary disclosure. Journal of Accounting and Economics, 1983, December. v. 5, n. 3, p. 179-194.

WALDEN, W. D.; SCHWARTZ, B. N. Environmental Disclosures and Public Policy Pressure. Journal of Accountig and Public Policy, n. 16, 1997. 
ANNEX - A

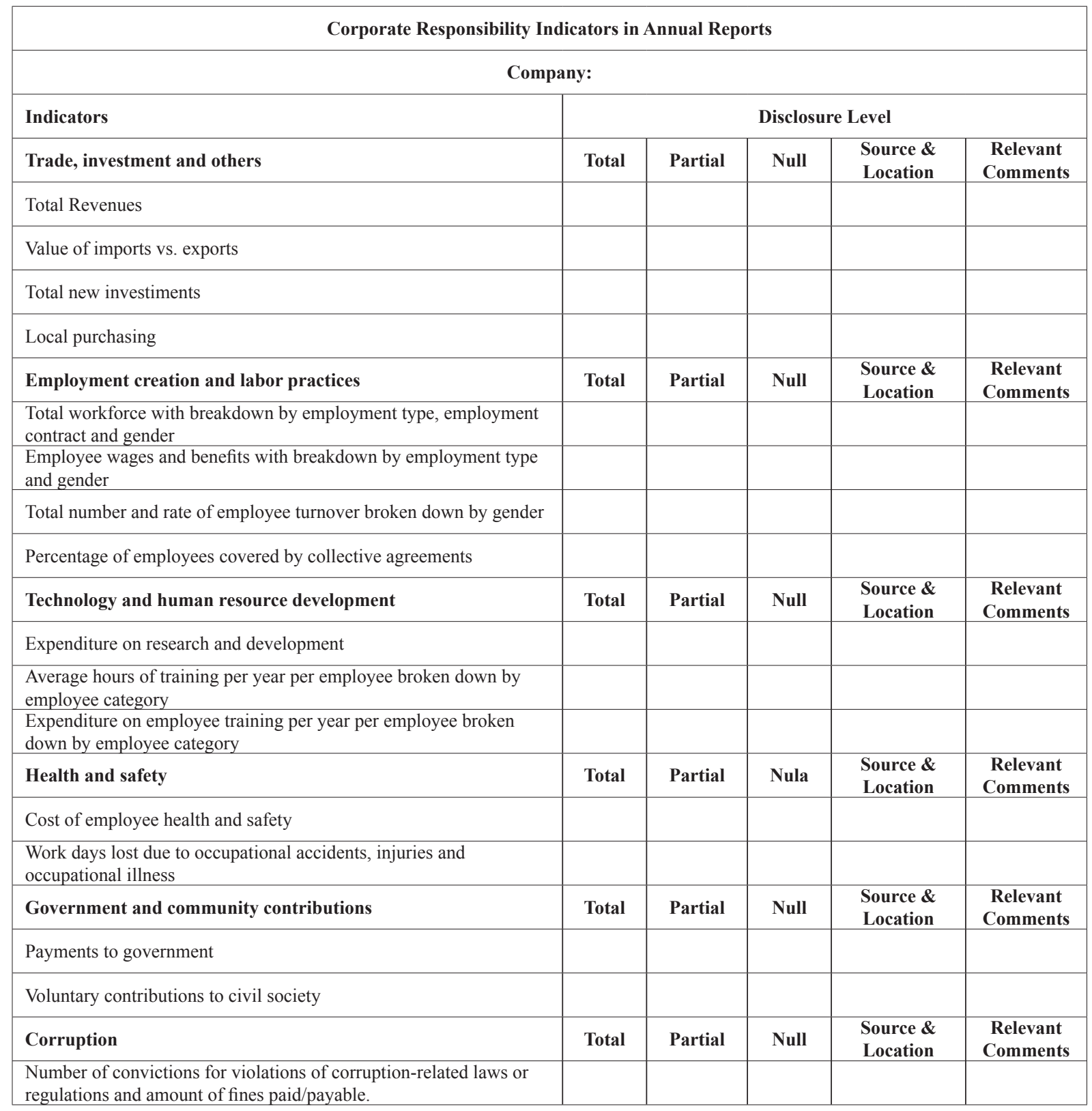

